\title{
ACUTE EXACERBATION IN CHRONIC HEPATITIS B VIRUS INFECTION
}

\section{Marcio Vieira Santos, Maria Irma Seixas Duarte and Antonio Alci Barone}

\begin{abstract}
A case of an acute exacerbation of liver injury in a cbronic HBV infected young male is reported. The correlation between the severe symptomatic bepatitis is done with the bistopathologic findings of extense areas of bridging necrosis on the liver biopsy. The serological pattern for markers of $\mathrm{HBV}\left(\mathrm{HB}_{s} \mathrm{Ag}+\right.$, anti $\mathrm{HB}_{S^{-}}, \mathrm{HB}_{e} \mathrm{Ag}-$, anti $\mathrm{HB}_{e}^{+}$, anti $H B_{C} \operatorname{Ig} G+$ and $\left.\operatorname{Ig} M-\right)$ confirm a chronic infection, and the authors propose that the episode of severe bepatitis relates to the recent spontaneous seroconvertion of $\mathrm{HB}$ Ag to anti $H B_{e}$. Other causes of hepatitis were excluded, and the control liver biopsy ( 6 months later) showed normalization of bepatic architecture and absence of markers of viral replication in tissue and serum. A review of literature is done in an attempt to elucidate the diagnostic possibilities in this case, with emphasis on new immunoassays useful in differentiating between acute bepatitis $B$ and acute exacerbation of a chronic bepatitis by the same virus.
\end{abstract}

Key-words: acute exacerbation. $H B_{e} A g$ - anti $H B_{e}$ seroconversion. Cbronic $H B V$ infection.

Chronic hepatitis B virus infection results in a spectrum of disease entities ranging from the most severe form of chronic active hepatitis to the asymptomatic carrier state of the Hepatitis B surface antigen $\left(\mathrm{HB}_{\mathrm{S}} \mathrm{Ag}\right)$. This wide range of liver injury among chronically infected hepatitis $B$ virus (HBV) patients suggests a great degree of variability in the interaction between the replicating virus and the immune responses to the infected hepatocyte?. It is well known that HBV - specific liver cell injury, and subsequent viral clearance, is believed to be mediated mainly by cellular immune mechanisms ${ }^{6}$.

Patients with chronic HBV infection can be generally divided into two groups:

A) Those with chronic liver disease (usually referred to as having chronic type $\mathrm{B}$ hepatitis [CHB]). These patients have markers of active viral replication, such as hepatitis $\mathrm{B}_{e}$ antigen $\left(\mathrm{HB}_{\mathrm{e}} \mathrm{Ag}\right.$ ) or HBV-DNA in serum or hepatitis $\mathrm{B}_{\mathrm{C}}$ antigen $\left(\mathrm{HB}_{\mathrm{C}} \mathrm{Ag}\right)$ in the liver, in addition to abnormal serum alanine aminotransferase

\footnotetext{
Laboratório de Investigação Médica em Hepatologia e de Patologia em Doenças Infecciosas, Departamento de Moléstias Infecciosas e Parasitárias, Hospital das Clínicas, Faculdade de Medicina da Universidade de São Paulo, São Paulo, SP.

Address to: Dr. Márcio Vieira Santos. Departamento de Moléstias Infecciosas e Parasitárias. HC/FMUSP. R. Dr. Enéias de Carvalho Aguiar 255, Cerqueira César, 05403-900 São Paulo, SP, Brasil.

Recebido para publicação em 10/02/95.
}

(ALT) activities and detectable $\mathrm{HB}_{\mathrm{S}} \mathrm{Ag}$ in serum and liver.

B) Those without liver disease, referred to as being in a "healthy" or "inactive" $\mathrm{HB}_{\mathrm{S}} \mathrm{Ag}$ carrier state. These patients have $\mathrm{HB}_{\mathrm{S}} \mathrm{Ag}$, but without HBV-DNA or $\mathrm{HB}_{\mathrm{e}} \mathrm{Ag}$ in serum, or detectable $\mathrm{HB}_{\mathrm{C}} \mathrm{Ag}$ and $\mathrm{HB} \mathrm{e}_{\mathrm{e}} \mathrm{Ag}$ in the liver, having, usually, normal serum ALT levels, no active inflammation or hepatocellular necrosis in the liver biopsies".

Studies on the natural history of chronic HBV infection indicate that these two groups probably represent two stages of chronic HBV infection: either spontaneously or during treatment, patients with CHB can lose HBVDNA and $\mathrm{HB}_{\mathrm{e}} \mathrm{Ag}$ from serum and then have a remission with subsequent appearance of antibody to $\mathrm{HB}_{\mathrm{e}} \mathrm{Ag}\left(\right.$ anti- $\mathrm{HB}_{\mathrm{e}}$ ). In this case, the disease usually evolves from chronic hepatitis to the "healthy" $\mathrm{HB}_{\mathrm{S}} \mathrm{Ag}$ carrier state. Seroconversion from $\mathrm{HB}_{e} \mathrm{Ag}$ to anti- $\mathrm{HB}_{e}$ is thus a "critical" event in the natural history of chronic HBV infection, and can occur directly after the acute phase (acute hepatitis) or it may happen years later, often following a flare-up of symptoms and increase in the ALT levels, or, in other words, presenting as an acute exacerbation in the evolution of a chronic hepatitis?.

A large percentage of patients with chronic active hepatitis (CAH) show a ciclic pattern 
Relato de Caso. Santos MV, Duarte MRS, Barone AA. Acute exacerbation in cbronic bepatitis B virus infection. Revista da Sociedade Brasileira de Medicina Tropical 29:275-279, mai-jun, 1996.

characterized by acute exacerbations of liver injury alternating with normal liver function, suggesting a dynamic interaction between the virus replication and the immune response'. Acute exacerbations in chronic B hepatitis are usually defined as episodes of abrupt elevation of ALT with or without significant symptom aggravation. Persistence of $\mathrm{HB}_{\mathrm{e}} \mathrm{Ag}$ after spontaneous flares is referred to as "abortive seroconversion".

We describe a case of an acute exacerbation of liver injury in a chronic HBV infected young male who probably acquired the disease in the neonatal or early childhood period, and was asymptomatic before this episode of acute exacerbation. Others causes of hepatitis were excluded by the available commercial assays and a percutaneous liver biopsy especimen was analised using immunohistochemical techniques.

\section{CASE REPORT}

HAF, a 15-year-old young male, natural from São Paulo - Brazil, looked for medical attention in April, $19^{\text {th }}$ 1994, with a 2 week history of right upper quadrant pain, jaundice, dark urine and a 4 day history of lethargy and change in personality. He denied fever, headache, diarrhoea, and his past medical history was unremarkable. There was no history of digestive or hepatic symptoms in the past. He denied intravenous drug addiction, sexual activity, previous blood transfusions, recent travel, as well as previous use of medications or exposure to toxins. The physical examination revealed an acutely ill, well developed patient with jaundice, without signs of chronic liver disease such as spiders, hepatomegaly, splenomegaly or ascites. The cardiac and pulmonary examination was normal. He was lethargic, confused, but there were no focal neurologic deficits, seizures or meningismus. The laboratory findings at admission and the serologic pattern are listed below:

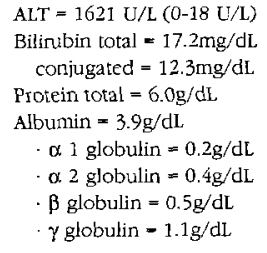

$\mathrm{ALT}=1621 \mathrm{U} / \mathrm{L}(0-18 \mathrm{U} / \mathrm{L})$ Bilinbin total $=17.2 \mathrm{mg} / \mathrm{dL}$ conjugated $=12.3 \mathrm{mg} / \mathrm{dL}$ Protein total $=6.0 \mathrm{~g} / \mathrm{dL}$ Albumin $=3.9 \mathrm{~g} / \mathrm{dL}$

$\alpha 1$ globulin $=0.2 \mathrm{~g} / \mathrm{dL}$

o. 2 globulin $=0.4 \mathrm{~g} / \mathrm{dL}$

$\beta$ globulin $=0.5 \mathrm{~g} / \mathrm{dL}$

$\gamma$ globulin $=1.1 \mathrm{~g} / \mathrm{dL}$

\author{
$\mathrm{Hb}=14.6 \mathrm{~g} / \mathrm{dL} \quad \mathrm{Hct}=48 \%$ \\ WBC count $=7.800 / \mathrm{mm}^{3}$ \\ neutrophils - bands $=3 \%$ \\ segmented $=49 \%$ \\ eosinophils - $2 \%$ \\ basophils - $0 \%$ \\ lymphocytes $-44 \%$ \\ monocytes - $2 \%$ \\ Plateler count: $308.000 / \mathrm{mm}^{3}$ \\ anti $\mathrm{HAV} \operatorname{IgG}+\mathrm{IgM}$ - \\ anti $\mathrm{HCV}$ - \\ HCV-RNA (PCR) - \\ anti HDV - \\ HBs Ag + anti HBs - \\ anti $\mathrm{HBC}$ IgG + IgM - \\ HBe Ag - Anti HBe +
}

Evolution. The patient was admitted to the intensive care unit and received supportive care for hepatic insufficiency, with prompt improvement in the level of consciousness. There were no bleeding complications, and the hepatic function improved to a level that an emergency hepatic transplantation was unnecessary. A percutaneous liver biopsy was done on May, $25^{\text {th }}, 1994$ and the hepatic tissue evidenced extense areas of bridging necrosis, either between portal zones or from portal zones to central veins. These necrotic areas had their reticulin framework colapsed and their hepatocytes had disappeared. The portal zones showed a moderate mononuclear cell infiltrate, without piecemeal necrosis or aggression to the bile ducts. A small number of neutrophils was also observed in the portal zones and necrotic areas. Ballooning degeneration, without evident aspect of ground-glass cell could also be noted in the preserved parenchyma. There was a discrete hypertrophy and hyperplasy of the Kupffer cells. No portal fibrosis was observed. The immunohistochemical technique revealed a small number of hepatocytes (less than 25\%) positive to $\mathrm{HB}_{S} \mathrm{Ag}$ and an absence of $\mathrm{HB}_{\mathrm{C}} \mathrm{Ag}$ or HDV Ag (antigen of the Hepatitis Delta Virus). At the time of the first biopsy, serum was collected and the PCR for HBV-DNA was negative.

Bridging necrosis found during acute viral hepatites indicates a serious lesion that can progress to postnecrotic cirrhosis or to "restitutio ad integrum". Because of this, another percutaneous liver biopsy was done 6 months after discharge (on December, $12^{\text {th }}, 1994$ ), and the specimen showed a practically normal hepatic architecture. The hepatocytes had no sign of degeneration or necrosis. The portal 
zones were not expanded and evidenced a mild limphocytic infiltration, which was also ocasionally observed in the lobular spaces. The hypertrophy and hiperplasy of Kupffer cells remained discrete. A small strip of intralobular fibrosis could be observed.The immunohistochemical technique had similar results when compared to the first examination: few hepatocytes expressing $\mathrm{HB}_{\mathrm{S}} \mathrm{Ag}$ and an absence of $\mathrm{HB}_{\mathrm{C}} \mathrm{Ag}$. The serological pattern for markers of HBV persisted exactly the same during the six month period of follow-up, with normalizaton of laboratory tests of hepatic function.

\section{DISCUSSION}

The serological pattern for markers of HBV, caracterized by the absense of detectable anti $\mathrm{HB}_{\mathrm{C}}$-IgM ruled out acute-phase infection by $\mathrm{HBV}^{5}$, as well as the negative results of IgM anti-HAV, anti-HCV antibodies and PCR for HCV-RNA in serum, antibody to HDV (antiHDV) and the negative result of immunohistochemical for HDV in the liver biopsy ruled out superinfections with other hepatotropic virus. The laboratory tests currently used for diagnosis of hepatitis E virus were not available at the time of patient illness : a serum sample was stored and tested retrospectively for antibodies to this new described virus, giving a negative reaction by the method of Elisa.

The serologic tests for intection with other non hepatotropic virus such as cytomegalovirus, Epstein-Barr virus were negative.

The absence of markers of viral replication of $\mathrm{HBV}$ virus ( $\mathrm{HB}_{\mathrm{e}} \mathrm{Ag}$ and $\left.\mathrm{HBV}-\mathrm{DNA}\right)$ in serum and the presence of anti- $\mathrm{HB}_{e}$, in addition to the absence of $\mathrm{HB}_{\mathrm{C}} \mathrm{Ag}$ in the liver indicates that active viral replication is subsiding and disease activity decreasing. Because those who have cleared $\mathrm{HB}_{\mathrm{e}} \mathrm{Ag}$ frequently have temporary exacerbations of hepatitis before the seroconversion, it has been suggested this event represents an "immune clearance" of hepatocytes containing actively replicating virus as well as $\mathrm{HBC} \mathrm{Ag} / \mathrm{HBe} \mathrm{Ag}^{6 \% ?}$.

The nucleocapside antigens of HBV (in the context of HLA antigens) are the most important target for cytoxicity. Recent studies on $\mathrm{T}$ cell response to HBV antigens during acute exacerbations of CHB demonstrated that the $\mathrm{T}$ cell proliferative response to recombinant $\mathrm{HB}_{\mathrm{C}}$
$\mathrm{Ag}$ and natural $\mathrm{HB}_{\mathrm{e}} \mathrm{Ag}$ was higher in patients with $\mathrm{CHB}$ than those in healthy $\mathrm{HB}_{\mathrm{S}} \mathrm{Ag}$ carriers, and that there was a further increase in $T$ cell proliferative response to $\mathrm{HB}_{\mathrm{C}} \mathrm{Ag} / \mathrm{HB}_{\mathrm{e}} \mathrm{Ag}$ during acute exacerbations. In the recovery from these acute exacerbations with $\mathrm{HB}_{\mathrm{e}} \mathrm{Ag}$ seroconvertion, the same study demonstrated a subsidence in $\mathrm{T}$ cell responses to the same antigens?.

Studying the alterations in quantitative serum HBV-DNA, $\mathrm{HB}_{\mathrm{e}} \mathrm{Ag}$ (as indicators of viral replication) and anti- $\mathrm{HB}_{\mathrm{e}}$ production, $\mathrm{HB}_{\mathrm{e}} \mathrm{Ag}$ specific immunocomplex formation (as indicators of an immune responsiveness) before, during and after injury in $\mathrm{HB}_{\mathrm{e}} \mathrm{Ag}$ positive patients with CAH, Maruyama et al ${ }^{6}$ showed that the increasing levels of viral replication occurred before the peak ALT levels, and then precipitously declined as ALT levels peaked and subsided. The indicators of immune responsiveness (anti-HBe and $\mathrm{HB}_{\mathrm{e}} \mathrm{Ag}$ specific immuno complex) increased in parallel with HBV-DNA/HB $\mathrm{e}$ Ag levels, with the exception of the anti-HB $\mathrm{H}_{\mathrm{e}}$ antibody, that peaked somewhat later than HBV-DNA/HB $\mathrm{Hg}$. The ability to produce anti $\mathrm{HBe}$ reflects the immune competence of these patients with $\mathrm{CAH}$, at least with respect to the $\mathrm{HB}_{\mathrm{e}} \mathrm{Ag}$ specific helper $\mathrm{T}$ cells and $\mathrm{B}$ cells, and is consistent with the possibility that the liver cell injury is mediated by immune mechanisms.

Another diagnostic possibility in this case is the existence of HBV precore mutants. Variants of $\mathrm{HBV}$ that do not express $\mathrm{HB}_{\mathrm{e}} \mathrm{Ag}$ have recently been described ${ }^{2}{ }^{3}$. The most common is the G-to-A switch at base 1896 of HBV-DNA precore region. The emergence of this precore mutants has been associated with fulminant hepatitis and severe liver disease in patients with anti- $\mathrm{HB}_{\mathrm{e}}$ positive chronic hepatitis ${ }^{1}$. In these cases, other markers of viral replication (as HBV-DNA) are expected to be present, and that was not shown in the present report, making this hypothesis less probable.

In some circunstances, it can be difficult to distinguish between an acute HBV infection from an acute exacerbation of a chronic HBV infection. This is true because, in contrast to most viral infections, patients with acute and chronic HBV often produce both immunoglobulin ( $\mathrm{Ig}) \mathrm{M}$ and $\mathrm{IgG}$ anti- $\mathrm{HB}_{\mathrm{C}}$ antibodies, and so, the quantitative difference in the levels of $\operatorname{IgM}$ anti-HB $\mathrm{C}_{\mathrm{C}}$ (higher level of IgM anti $\mathrm{HB}_{\mathrm{C}}$ are generally produced during 
acute phase infection) can be the only serological means of differentiating this situation, what is important in terms of prognosis and possible treatment modalities ${ }^{\top}$. Recent studies have focused on the serology of chronic HBV infections, using assays capable of detecting antibody to $\mathrm{HB}_{\mathrm{e}} \mathrm{Ag}$ and $\mathrm{HB}_{\mathrm{S}} \mathrm{Ag}$ in the presence of circulating $\mathrm{HB}_{\mathrm{e}}$ and $\mathrm{HB}_{\mathrm{s}}$ $\mathrm{Ag}^{7}$. The use of these experimental immunoassays has modified our view of the serology of chronic HBV infection by showing that virtually all $\mathrm{HBV}$ chronic carriers with liver disease are positive for both $\mathrm{HB}_{\mathrm{e}} \mathrm{Ag}$ and anti$\mathrm{HBe}$ for many years before the loss of $\mathrm{HB}_{e} \mathrm{Ag}$, and anti-HB $\mathrm{H}_{\mathrm{S}}$ production can be detected as $\mathrm{HB}_{\mathrm{S}} \mathrm{Ag}$ - specific immune complexes (ICs) in parallel with liver damage in $\mathrm{CAH}$ patients?

These same experimental assays, when applied to acute $\mathrm{HBV}$ infection reveal that patients with CHB show significantly higher levels of free anti-HBe, $\mathrm{HB}_{e} \mathrm{Ag} /$ anti-HB $\mathrm{HB}_{\mathrm{e}} \mathrm{ICs}$ and $\mathrm{HB}_{\mathrm{S}} \mathrm{Ag} /$ anti-HBs ICs compared with acute HBV patients sera. Furthermore, the most significant and possibly the most useful difference in the serology of patients with acute and chronic $\mathrm{HBV}$ is the presence of a novel specificity of IgG anti-HB $\mathrm{HB}_{\mathrm{c}}$ antibody designated as anti WHBC antibodies. Previous studies have indicated that the nucleocapsides of $\mathrm{HBV}$ and the Woodchuck hepatitis virus (another member of the Hepadnaviridae family) share a cross-reactive epitope(s). So, it is demonstrated that human anti- $\mathrm{HB}_{\mathrm{C}}$ antibodies recognize Woodchuck $\mathrm{HB}_{\mathrm{C}} \mathrm{Ag}$ $\left(\mathrm{WHB}_{\mathrm{C}} \mathrm{Ag}\right.$ ), and that $\mathrm{CHB}$ patient sera show significantly higher levels of IgG anti- $\mathrm{WHB}_{\mathrm{C}}$ compared with acute hepatitis $\mathrm{B}$ patient sera, without overlap values. The same authors propose a ratio of $\operatorname{IgM}$ anti- $\mathrm{HB}_{\mathrm{C}} / \mathrm{IgG}$ anti$\mathrm{WHB}_{C}$ that could be performed in acute and chronic HBV infections in order to discriminate between acute hepatitis $B$ from symptomatic chronic hepatitis $B$ infection: an inverse correlation between IgM anti-HB $\mathrm{H}_{\mathrm{C}}$ and IgG anti-WHB ${ }_{C}$ values existed in both patients with acute and chronic HBV infection?

Recent studies on the prevalence of $\mathrm{HB}_{\mathrm{S}} \mathrm{Ag}$ subtypes (adr, adw, ayr and ayw) have demonstrated differences in their geographic distribution and their relationship with epidemiologic factors. More recently, $\mathrm{HB}_{\mathrm{S}} \mathrm{Ag}$ subtypes have been associated with $\mathrm{HB}_{\mathrm{e}}$ $\mathrm{Ag} /$ anti $\mathrm{HB}_{e}$ status and may, consequently, influence the development of liver disease in the $\mathrm{HB}_{\mathrm{S}} \mathrm{Ag}$ carriers. For example, in a restricted geographic area of Japan, with a homogenous epidemiological/cultural background, adr carriers tend to be seroconverted to anti-HBe at an older age than adw carriers, and thus, adr carriers may develop chronic liver disease more frequently than adw carriers ${ }^{8}$. Data on HBs Ag subtypes prevalence in our geographic region (São Paulo - Brazil) are not available, so, conclusions based in the $\mathrm{HB}_{\mathrm{S}}$ Ag subtype of our patient could not be done, and it was not determined.

Various average annual conversion rates for $\mathrm{HB}_{\mathrm{e}} \mathrm{Ag}$ to anti-HB $\mathrm{e}$ have been reported in adults; these rates range from $2.3 \%$ to $25 \%$ in various parts of the world ${ }^{*}$. With respect to other factors affecting the clearance of $\mathrm{HB}_{e} \mathrm{Ag}$ specifically in children, studies have shown that the presence of symptoms, a negative maternal $\mathrm{HB}_{\mathrm{S}} \mathrm{Ag}$ status, and the infection occurring later in life, are correlated with a higher $\mathrm{HB}_{\mathrm{e}}$ Ag clearance rate-

The patient reported in this review was a 14 years old boy that denied the most important risk factors related to HBV infection, including sexual activity. His mother serum was obtained and the biochemical and serologic analysis revealed a normal hepatic function and a negative result for $\mathrm{HB}_{S} \mathrm{Ag}$ with a positive result for anti- $\mathrm{HB}_{\mathrm{S}}$ and anti-HB $\mathrm{C}$ IgG antibodies, proving a previous contact with HBV with adquired resistance to $\mathrm{HBV}$ infection. So, it is possible to assume that our patient had probably been infected during the perinatal period by his mother, or during early childhood. At least, it is possible to infer that sometime in her life, the patient's mother had active HBV replication, and was able to transmit HBV to her infants or household contacts.

In conclusion, we postulate that the acute and serious exacerbation of liver injury presented here is related to the immune clearance of hepatocytes expressing HBV nucleocapside antigens acumulated intracellularly after a period of increased replication. Probably, as the serum $\mathrm{HB}_{\mathrm{e}} \mathrm{Ag}$ concentration reached a threshold level, $\mathrm{HB}_{\mathrm{e}} / \mathrm{HB}_{\mathrm{C}} \mathrm{Ag}$ specific TH cells became activated, resulting in anti-HBe production. Similarly, $\mathrm{HB}_{\mathrm{e}} / \mathrm{HB}_{\mathrm{C}} \mathrm{Ag}-$ specific citotoxic $\mathrm{T}$ lymphocytes (CTL) were induced, favoring cell-mediated immunity and resulted in an efficient viral clearance mechanism of hepatocytes producing 
Relato de Caso. Santos MV, Duarte MRS, Barone AA. Acute exacerbation in chronic hepatitis B virus infection. Revista da Sociedade Brasileira de Medicina Tropical 29:275-279, mai-jun, 1996.

nucleocapside antigens, but sparing the hepatocytes exclusively producing $\mathrm{HB}_{S} \mathrm{Ag}$, resulting in an improvement of clinical/laboratorial and histopathologic findings, with change to the "healthy" $\mathrm{HB}_{\mathrm{S}} \mathrm{Ag}$ carrier state.

\section{RESUMO}

Descreve-se um caso de exacerbação aguda sintomática em um paciente cronicamente infectado pelo VHB, mostrando-se correlação entre o quadro clínico grave (com insuficiência bepática transitória) e os achados bistopatológicos de bepatite severa com extensas áreas de necrose en ponte. $O$ perfil sorológico para marcadores do $\mathrm{VHB}\left(\mathrm{Ag}_{\mathrm{g}} H \mathrm{~B}_{S}\right.$ ${ }^{+}$, anti $H B_{S}$-, $A g H B_{e}$-, anti $H B_{e}+$, anti $H B_{C} \operatorname{IgG}+$ IgM -) confirmou infecção crônica, e os autores levantam a bipótese de que a bepatite tenba se correlacionado à recente soroconversão $\mathrm{Ag} \mathrm{HB} e$

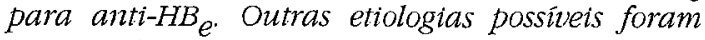
descartadas $e$ se contou com biopsia controle 6 meses depois, mostrando normalização da arquitetura hepática e ausência de marcadores de replicação viral no tecido e no soro. Revisa-se a literatura sobre o diagnóstico diferencial cabivel nesta situação, dando ênfase a novos ensaios sorológicos üteis na diferenciação entre infecção aguda pelo $V H B$ e exacerbação aguda de uma bepatite crônica pelo mesmo agente.

Palavras-chaves: Exacerbação aguda. Soroconversão $A g H B e^{-a n t i} H_{e}$ infecção crônica pelo $\mathrm{VHB}$.

\section{REFERENCES}

1. Bortolotti F, Crivellaro C, Brunetto MR, Cadrobbi P, Bertolini A, Alberti A. Selection of a precore mutant of hepatitis $B$ virus and reativation of chronic hepatitis B acquired in childhood. The Journal of Pediatrics 123:583-585, 1993.

2. Brunetto MR, Stemler M, Shodel F, Will H, Ottobrelli M, Rizzetto M, Verme G, Bonino F.
Identification of $\mathrm{HBV}$ variants which cannot produce precore derived $\mathrm{HB}_{\mathrm{e}} \mathrm{Ag}$ and may be responsible for severe hepatitis. Italian Journal of Gastroenterology 21:151-154, 1989.

3. Carman WF, Jacyna MR, Hadziyannis $S$, Karayiannis P, McGarvey MJ, Markis A, Thomas HC. Mutation preventing formation of hepatitis $B_{e}$ antigen in patients with chronic hepatitis $B$ infection. Lancet 2:588-590, 1989.

4. Chang MH, Sung JL, Lee CY, Chen CJ, Chen JS, Hsu HY, Lee PI, Chen DS. Factors affecting clearance of Hepatitis $B_{e}$ antigen in hepatitis $B$ surface antigen carrier children. The Journal of Pediatrics 115:385-390, 1989.

5. Decker, RH. Diagnosis of hepatitis B virus. In: Viral hepatitis. Scientific basis and clinical managements. Churchill Livingstone, p 165-184, 1993.

6. Maruyama T, Lino S, Koike K, Yassuda K, Milich DR. Serology of acute exacerbation in chronic hepatitis B virus infection. Gastroenterology 105:1141-1151, 1993.

7. Maruyama T, Schodel $F$, Iino $S$, Koike $K$, Yasuda $K$, -Peterson D, Milich DR. Distinguishing between acute and symptomatic chronic Hepatitis B virus infection. Gastroenterology 106:1006-1015, 1994.

8. Noguchi A, Heyashi J, Nakashima $K$, Hirata $M$, Ikematsu $\mathrm{H}$, Kashiwagi S. HBs Ag subtypes among HBs Ag carriers in Okinawa, Japan. Evidence of an important relationship in seroconversion from $\mathrm{HB}_{\mathrm{e}} \mathrm{Ag}$ to anti-HB $\mathrm{e}_{\mathrm{e}}$ Journal of Infection 28:141-150, 1994.

9. Tsai SL, Chen PJ, Lai My, Yang PM, Sung JL, Huang $\mathrm{JH}$, Hwang $\mathrm{LH}$, Chang TH, Chen DS. Acute exacerbations of chronic type $B$ hepatitis are accompanied by increased $T$ cell responses to hepatitis $B$ core and $e$ antigens. Implications for hepatitis $\mathrm{B}_{\mathrm{e}}$ antigen seroconversion. Journal of Clinical Investigation 89:87-96, 1992. 